Jurnal Natur Indonesia 14(1), Oktober 2011: 42-46

ISSN 1410-9379, Keputusan Akreditasi No 65a/DIKTI/Kep./2008

\title{
Kemampuan Kitinase Streptomyces RKt5 sebagai Antijamur terhadap Patogen Fusarium oxysporum
}

\author{
Yurnaliza $^{1 *)}$, Sebastian Margino ${ }^{2)}$ dan Langkah Sembiring ${ }^{3)}$ \\ ${ }^{1)}$ Departemen Biologi, Fakultas Matematika dan Ilmu Pengetahuan Alam, Universitas Sumatera Utara, Medan 20155 \\ ${ }^{2)}$ Fakultas Pertanian, Universitas Gadjah Mada, Yogyakarta 55281 \\ ${ }^{3}$ Fakltas Biologi, Universitas Gadjah Mada, Yogyakarta 55281 \\ Diterima 11-05-2010Ｄisetujui 11-05-2011
}

\begin{abstract}
The purpose of the reasearch is to determine of antifungal activity from chitinase from Streptomyces RKt5 to inhibite growth of Fusarium oxysporum. The chitinase of Streptomyces RKt5 produced in liquid chitin medium with optimum conditions (inoculum concentration, $\mathrm{pH}$ and incubation time) and then partially purified with ammonium sulphate. The enzyme products were tested the antifungal activity against F.oxysporum. The results showed that mycelial growth of F.oxysporum can be inhibited by Streptomyces RKt 5 in dual culture test. The partial purified chitinase enzyme couldn't inhibit the fungal growth. But if the mycellium fragmented, the enzyme could degrade the fungal cell wall in incubation time. The frequency of fungal cell wall lysis and levels of $\mathrm{N}$-acetylglucosamine released that have been increasing along with the length of incubation time.
\end{abstract}

Keywords: antifungal, chitinase, Fusarium oxysporum, Streptomyces RKt5

\section{PENDAHULUAN}

Kitinase merupakan enzim hidrolitik yang dapat mendegradasi kitin yaitu polimer dari b-1,4 N-setil-Dglukosamin. Senyawa ini terdapat melimpah di alam dan dapat ditemukan pada kerangka insekta, krustase dan dinding sel jamur (Nwe et al. 2011). Proses degradasi kitin di alam dilakukan oleh beberapa jenis jamur, bakteri, aktinomisetes dan tumbuhan (Matsumoto 2006). Kitinase adalah enzim kompleks yang umumnya terdiri dari beberapa jenis enzim yang dibedakan berdasarkan kerjanya yaitu endokitinase (EC. 3.2.1.14), eksokitinase dan b-1,4-Nasetilglukosamidase (EC. 3.2.1.30) (Sahai \& Manocha 1993). Kitinase juga dikelompokkan berdasarkan urutan asam aminonya dan dibagi atas tiga famili yaitu famili 18, 19 dan 20. Famili 18 meliputi kitinase dari bakteri, jamur, serangga, tanaman (kelas III dan V) dan hewan. Famili 19 diidentifikasi dari tanaman (kelas I, II, dan IV) dan bakteri gram positif Streptomyces, sedangkan famili 20 dari Vibrio harveyi (Watanabe et al. 1999; Patil et al. 2000).

Mikroorganisme kitinolitik saat ini banyak diteliti terutama kemampuannya sebagai agen pengendali hayati penyakit tumbuhan terutama yang disebabkan oleh jamur patogen (Shaikh \& Deshpande 1993; Patil et al. 2000; Gohel et al. 2006). Jamur umumnya memiliki dinding sel yang mengandung senyawa kitin. Kehadiran mikroorganisme kitinolitik di tanah terutama pada rhizoplane dan filoplane tanaman dapat melindungi tanaman dari infeksi jamur. Kitin yang terdapat pada dinding sel jamur patogen dapat didegradasi atau dilisiskan oleh mikroorganisme kitinolitik sehingga mengurangi terjadinya infeksi penyakit.

Kitin yang terdapat pada dinding sel jamur terikat bersama komponen dinding sel lainnya seperti glukan, mannan dan protein. Jumlah kitin pada dinding sel jamur tidak sama untuk setiap jenis. Secara umum kandungan kitin dan kitosan pada spesies jamur berbeda bervariasi dari $2-60 \%$ berat kering miselium. Kandungan kitin juga bervariasi diantara jenis dalam genus yang sama (KnezevicJugovic et al. 2011). Jamur kelas Ascomycetes, Zygomycetes, Basidiomycetes dan Deuteromycetes umumnya mengandung kitin. Sedangkan Kelas Oomycetes dominan glukan. Kitin pada jamur berbentuk mikrofibril yang memiliki panjang berbeda tergantung pada spesies dan lokasi selnya. Mikrofibril merupakan penyusun utama struktur dinding sel jamur dan terdiri dari rantai-rantai polisakarida yang saling bersilangan membentuk anyaman. Polimer lain penyusun dinding sel jamur seperti glukan, mannan dan protein ikut memperkokoh struktur dinding sel jamur (Knezevic-Jugovic et al. 2011).

Mikroorganisme dengan kemampuan kitinolitik diyakini mampu berperan mengendalikan serangan jamur perusak tanaman dengan menjadikan kitin sebagai sumber karbon dan nitrogen (Gohel et al. 2006; Kamil et al. 2007). 
Beberapa kelompok bakteri dan jamur dengan kemampuan kitinolitik dipakai dalam mengendalikan patogen tanaman seperti Bacillus (Huan et al. 2005), Enterobacter (Chernin et al. 1995), jamur Trichoderma (Harjono \& Widyastuti 2001; Harighi et al. 2007) dan Streptomyces (Sadeghi et al. 2006). Prapagdee et al. (2008), menyatakan bahwa $S$. hygroscopicus secara in vitro bersifat antagonis terhadap Colletotrichum gloeosporioides and Sclerotium rolfsii dan menghambat pertumbuhan jamur patogen dengan aktivitas enzim hidrolitik seperti kitinase dan glukanase.

Pada penelitian sebelumnya telah ditemukan isolat Streptomyces RKt 5 yang diisolasi dari rizosfer kacang tanah dengan kemampuan kitinolitik tinggi (Yurnaliza et al. 2003). Bakteri ini menghasilkan enzim kitinase dengan aktivitas optimum pada pH 5,5 dan suhu $50^{\circ} \mathrm{C}$ (Yurnaliza et al. 2008). Kemampuan antijamur bakteri ini akan diujikan terhadap jamur Fusarium oxysporum. Jamur ini merupakan patogen asal tanah yang penting secara ekonomi, karena dapat menyebabkan busuk dan layu Fusarium pada akar, batang dan kecambah pada lebih dari 100 jenis tanaman. Pengendalian penyakit ini sulit dilakukan karena jamur dapat bertahan lama di tanah sebagai saprofit. Maka pada penelitian ini akan dikaji kemampuan Streptomyces RKt5 sebagai antijamur terutama dalam melisiskan dinding sel jamur Fusarium oxysporum.

\section{BAHANDANMETODE}

Biakan Streptomyces RKt-5 (Yurnaliza et al. 2003). Jamur patogen uji yaitu Fusarium oxysporum isolat bawang merah. Jamur ini disimpan pada biakan miring medium Potato Dekstrosa Agar (PDA). Enzim kitinase dari Streptomyces RKt 5 diproduksi pada medium kitin cair yang mengandung garam minimal dan 0,2 \% koloidal kitin (Hsu \& Lockwood 1975). Medium mineral dalam setiap liternya terdiri dari $0,7 \mathrm{~g} \mathrm{~K}_{2} \mathrm{HPO}_{4} ; 0,3 \mathrm{~g} \mathrm{KH}_{2} \mathrm{PO}_{4} ; 0,5 \mathrm{~g} \mathrm{MgSO}_{4} 7 \mathrm{H}_{2} \mathrm{O} ; 0,01 \mathrm{~g}$ FeSO $47 \mathrm{H}_{2} \mathrm{O} ; 0,001 \mathrm{~g} \mathrm{ZnSO}_{4} ; 0,001 \mathrm{~g} \mathrm{MnCl}_{2}$. Koloidal kitin dipreparasi dari Chitin Shrimp shells (Sigma) secara hidrolisis parsial menggunakan $\mathrm{HCl} 10 \mathrm{~N}$ (Labeda \& Shearer 1990).

Produksi Kitinase. Produksi kitinase dilakukan menurut Yurnaliza et al. (2008), dengan penambahan $5 \%(\mathrm{v} / \mathrm{v})$ starter, $\mathrm{pH}$ medium 6,8 dan suhu ruang selama 72 jam. Pemanenan enzim dilakukan dengan sentrifugasi pada $4000 \mathrm{rpm}$ selama 20 menit pada suhu $4^{\circ} \mathrm{C}$. Supernatan dipresipitasi dengan ammonium sulfat pada kejenuhan $70 \%$ (b/v). Presipitat didialisis semalam pada suhu $4^{\circ} \mathrm{C}$ menggunakan $10 \mathrm{mM}$ buffer fosfat $\mathrm{pH}$ 6,8 dalam kantong dialisis dengan membran yang mempunyai molecular weight cut off 12.000 (Sigma). Satu unit aktivitas enzim kitinase didefinisikan sebagai jumlah enzim yang membebaskan sebanyak $\mu$ mol NAG/jam. N-asetilglukosamin (NAG) yang dihasilkan dianalisis secara kolorimetri menurut metode Reissig (1955), (Muzarelli \& Peter 1997). Penentuan jumlah protein terlarut ditentukan dengan metode Lowry (Plummer 1978).

Uji Antagonis antara Bakteri Streptomyces RKt 5 dan F.oxysporum. Uji antagonis dilakukan untuk melihat kemampuan bakteri Streptomyces RKt5 menghambat pertumbuhan jamur F.oxysporum pada kondisi terinduksi kitin. Pada bagian tengah cawan petri yang berisi media kitin agar, ditumbuhkan jamur F.oxysporum. Pada kedua sisi koloni jamur dengan jarak yang sama, diinokulasi biakan Streptomyces RKt 5. Zona jernih di sekeliling koloni Streptomyces RKt 5 menunjukkan terjadinya hidrolisis kitin. Jamur F.oxysporum yang tumbuh pada tengah cawan petri akan berinteraksi dengan zona hidrolisis dan koloni Streptomyces RKt5. Interaksi yang terjadi antara bakteri Streptomyces RKt5 dan jamur F.oxysporum, diamati secara visual, dan dideskripsikan secara kualitatif. Inkubasi dilakukan sampai 21 hari dan dicatat perubahan yang terjadi pada pertumbuhan jamur F.oxysporum.

Uji kemampuan antijamur enzim kitinase. Uji kemampuan antijamur enzim kitinase ditentukan berdasarkan adanya penghambatan-pemanjangan miselium jamur F.oxysporum saat terjadi kontak dengan enzim kitinase (Bormann et al. 1999). Pada pinggir miselium jamur umur 3 hari di medium PDA, diletakkan cakram kertas yang telah direndam cairan enzim hasil purifikasi (konsentrasi $8,92 \mathrm{mg}$ prot $/ \mathrm{ml}$ ) dengan jarak $1 \mathrm{~cm}$ dari pinggir koloni jamur. Kontrol digunakan cakram kertas yang direndam dengan akuades steril. Hambatan pemanjangan miselium F. oxysporum yang mengarah ke cakram yang berisi enzim dan akuades (kontrol) diamati secara visual setelah 12 jam inkubasi pada suhu kamar.

Lisis dinding sel jamur Fusarium oxysporum. Kemampuan enzim kitinase dalam melisiskan dinding sel jamur ditentukan dengan melihat perubahan yang terjadi pada miselium jamur setelah dicampur dengan enzim kitinase. Miselium jamur F. oxysporum ditumbuhkan dalam medium PDB selama 5 hari pada suhu $30^{\circ} \mathrm{C}$. Miselium dipanen dan disaring dengan kertas saring Whatman No. 1, kemudian dicuci dengan akuades steril beberapa kali. Miselium dipotong menggunakan waring blender selama 15 detik pada kecepatan lambat (low speed), dan kemudian 
disentrifus selama 10 menit pada $4000 \mathrm{rpm}$. Pelet miselium dicuci kembali dengan akuades steril dan disuspensikan ke dalam $50 \mathrm{mM}$ buffer sitrat $(\mathrm{pH} 5,5)$ yang mengandung $100 \mathrm{mM} \mathrm{NaCl}$ dan $\mathrm{NaN}_{3}$ 0,05\%. Suspensi miselium dan enzim kitinase (konsentrasi 8,92 mg prot/ml) dicampur dengan perbandingan $1: 1$ dan diinkubasi pada suhu $35^{\circ} \mathrm{C}$ (Singh et al. 1999). Perubahan yang terjadi pada miselium diamati dengan menggunakan mikroskop cahaya perbesaran 400 kali, setelah inkubasi 1, 2, 4 dan 6 jam. Kontrol adalah miselium jamur yang tanpa perlakuan enzim. Miselium jamur diwarnai dengan laktofenol blue. Kadar N asetil glukosamin yang dibebaskan dari dinding sel jamur ditentukan secara kolorimetri dengan metode Reissig (1955), (Muzarelli \& Peter 1997).

\section{HASIL DAN PEMBAHASAN}

Produksi kitinase pada kondisi optimal dengan penambahan $5 \%(\mathrm{v} / \mathrm{v})$ starter, $\mathrm{pH}$ medium 6,8 pada suhu ruang selama 72 jam, dihasilkan kitinase dengan aktivitas spesifik 2,13 U/mg-1. Pada purifikasi secara parsial dilakukan aktivitas spesifik enzim ini meningkat sebanyak 3,13 kali kemurniannya dibandingkan dengan aktivitas spesifik enzim kasarnya.

Hasil uji antagonis antara Streptomyces RKt-5 dan jamur $F$. oxysporum pada medium kitin agar (Gambar 1) menunjukkan adanya hambatan pertumbuhan jamur. Pengamatan dilakukan pada waktu inkubasi 14 hari dan 21 hari. Pada 14 hari hambatan pertumbuhan miselium jamur terdapat di sekeliling koloni Streptomyces RKt5 (Gambar 1a) dan pada 21 hari hambatan pertumbuhan menjadi semakin besar (Gambar 1b). Hambatan pertumbuhan miselium jamur F.oxysporum diduga tidak hanya disebabkan oleh enzim kitinase, melainkan juga karena enzim dan metabolit lain yang juga dihasilkan oleh Streptomyces RKt5.

Pada uji kemampuan antijamur enzim kitinase hasil purifikasi parsial terhadap miselium jamur F. oxysporum, tidak
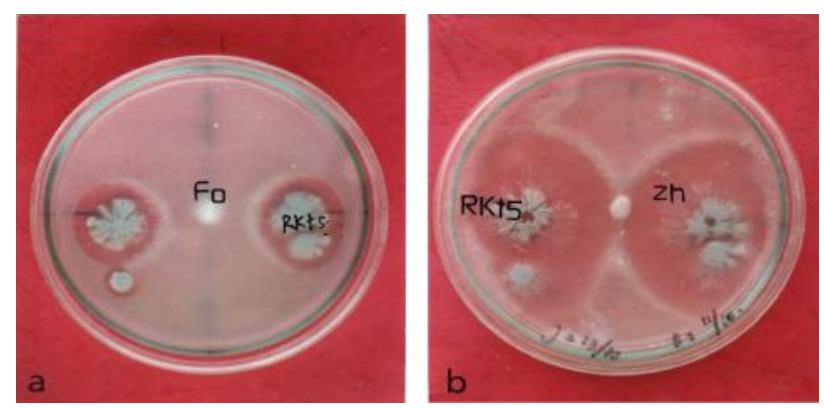

Gambar 1 Aktivitas antijamur Streptomyces RKt5 terhadap pertumbuhan miselium jamur F.oxysporum pada media kitin agar pada inkubasi 14 (a) dan 21 hari (b). Zh (zona lisis), Fo (F.oxysporum), Rkt5 (Streptomyces Rkt5) ditemukan adanya perubahan pada pertumbuhan jamur. Pada Gambar 2, dapat dilihat bahwa tidak ada perbedaan nyata antara pertumbuhan miselium jamur pada kedua sisi cakram yang ditetesi enzim kitinase (E) dan kontrol (K). Enzim kitinase yang diujikan tidak dapat menghambat pertumbuhan koloni jamur. Ada dua kemungkinan yang menyebabkan hal ini terjadi, pertama adalah komposisi dinding sel dari jenis jamur uji yang digunakan dan kedua konsentrasi enzim kitinase yang digunakan untuk uji.

Jamur $F$. oxysporum dibandingkan jamur patogen lainnya lebih tahan terhadap lisis. Sivan dan Chet (1989), melaporkan bahwa dua isolat Trichoderma harzianum gagal mendegradasi jamur $F$. oxysporum dibandingkan dengan jamur lain dari kelas Ascomycetes dan Basidiomycetes seperti Rhizoctonia solani dan Sclerotium rolfsii. Padahal jamur ini mampu menghasilkan enzim kitinase dan b-1,3 glukanase ke dalam medium jika ditumbuhkan pada medium yang mengandung kitin dan laminarin. Ia berpendapat bahwa beberapa protein dan lipid yang melapisi dinding sel menghalangi aktivitas enzim kitinase. Penelitian Kamel et al. (1993), menggunakan miselium jamur F. oxysporum dan Rhizoctonia solani yang sama-sama diperlakukan dengan enzim kitinase selama 5 menit menunjukkan bahwa miselium jamur $F$. oxysporum juga lebih tahan terhadap pengaruh enzim tersebut dibandingkan dengan jamur $R$. solani. Berbeda dengan penelitian yang dilakukan oleh Harjono dan Widyastuti (2001); Harighi et al. (2007), yang masing masing mengujikan kemampuan antijamur kitinase murni dari Trichoderma atroviride PTTC5220 dan Trichoderma ressei terhadap jamur Rhizoctonia solani dan Ganoderma philippii. Hasil penelitian menunjukkan bahwa kitinase murni yang diujikan mampu menghambat pertumbuhan miselium jamur uji. Enzim endokitinase murni dari Trichoderma ressei pada konsentrasi 100-200 $\mu \mathrm{g} / \mathrm{ml}$, dapat melisiskan ujung hifa G.philippii.

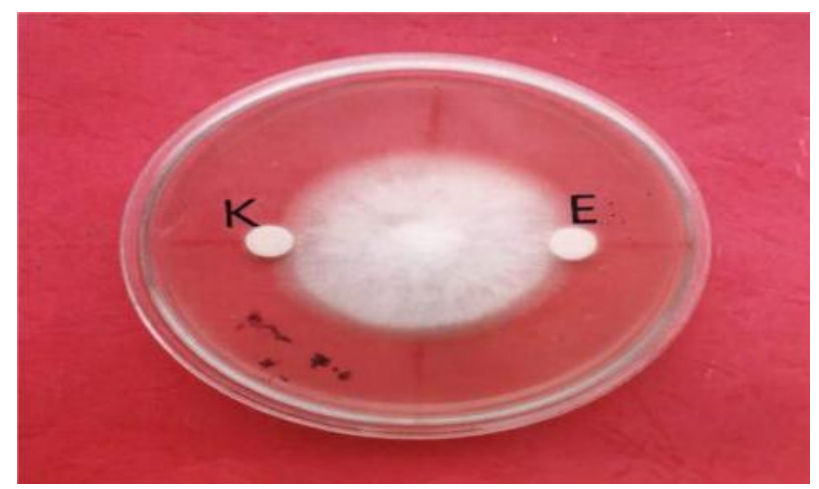

Gambar 2 Aplikasi enzim kitinase hasil purifikasi parsial (E) dan akuades steril (K) terhadap pemanjangan miselium jamur F. oxysporum 
Pengujian kemampuan antijamur enzim kitinase pada jenis jamur yang berbeda memberikan hasil yang berbeda. Jamur F.oxysporum memang lebih tahan terhadap kitinase karena komposisi dinding selnya berbeda dengan jamur R.solani atau Ganoderma. Schoffelmeer et al. (1999), menyatakan bahwa komposisi dinding sel dari jamur F.oxysporum pada lapisan luar terdapat senyawa glikoprotein yang melindungi permukaan miselium. Sementara kitin dan glukan terdapat pada lapisan dalam. Kandungan glikoprotein pada dinding sel sebanyak 50-60\% dari total massa dinding sel, dimana dari hasil analisis gula yang terdapat pada dinding sel dari tiga forma spesialis F.oxysporum menunjukkan bahwa jamur ini tidak hanya mengandung glukosa dan ( $\mathrm{N}$-asetil) glukosamin tetapi juga mannosa, galaktosa dan asam uronik yang diduga berasal dari glikoproptein dinding sel.

Kitinase dalam aktivitas penghambatannya membutuhkan enzim lain yang bekerja simultan dalam menghambat pertumbuhan jamur uji. Hambatan pertumbuhan terjadi pada miselium jamur yang ditumbuhkan bersama dengan Streptomyces RKt5 pada media yang mengandung kitin. Kitin yang ditambahkan menginduksi enzim kitinase dan juga Streptomyces RKt5 mengaktifkan enzim-enzim hidrolitik lainnya untuk menghambat pertumbuhan jamur. Penjelasan dari fenomena ini adalah kitinase aktinomisetes akan lebih efektif menghambat pertumbuhan jamur F.oxysporum jika terdapat bersama-sama dengan mikroorganisme penghasilnya dalam keadaan terinduksi kitin.

Miselium jamur yang utuh sulit untuk ditembus oleh kitinase murni, dan aktivitas enzim ini akan efektif jika miselium jamur yang diujikan telah berada dalam bentuk potongan-potongan. Enzim kitinase mampu melisiskan potongan dinding sel jamur F.oxysporum yang diberikan dengan konsentrasi yang sama dengan pengujian sebelumnya. Secara mikroskopis miselium jamur yang terpapar kitinase menunjukkan perubahan bentuk jika dibandingkan dengan miselium yang hanya ditetesi akuades steril. Fragmentasi miselium $F$. oxysporum diamati mulai sejak inkubasi 1 sampai 6 jam. Miselium jamur pada awalnya panjang-panjang dan utuh (Gambar 3a), setelah 1 jam mulai terpotong menjadi bagian yang lebih pendek (Gambar 3b). Potongan miselium jamur yang diinkubasi selama 2 jam (Gambar 3c) lebih pendek dibanding pada miselium yang dinkubasi 1 jam dan yang diinkubasi selama 4 jam (Gambar 3d) lebih pendek dari yang diinkubasi 2 jam, demikian seterusnya sampai waktu inkubasi 6 jam. Semakin lama waktu inkubasi, ukuran miselium jamur F. oxysporum menjadi semakin pendek dan sedikit. Hampir seluruh bagian miselium jamur menjadi hancur dan lisis pada waktu inkubasi 6 jam (Gambar 3e).

Terjadinya lisis pada dinding sel jamur F.oxysporium ditandai dengan meningkatnya jumlah NAG pada medium. Pada inkubasi 2 jam dibebaskan sebanyak 84,30 $\mu \mathrm{g} / \mathrm{ml}$ NAG, dan meningkat terus pada jam ke-4 dan 6 menjadi sebanyak $213,63 \mu \mathrm{g} / \mathrm{ml}$ dan 227,78 $\mu \mathrm{g} / \mathrm{ml}$ (Gambar 4). NAG yang terdapat pada medium berasal dari miselium jamur yang melisis.

Kitinase melisiskan dinding sel miselium yang telah dipotong-potong dengan blender. Kitin pada dinding sel dengan mudah dirombak. Protein dan lemak tidak menghalangi masuknya enzim ke bagian dinding miselium
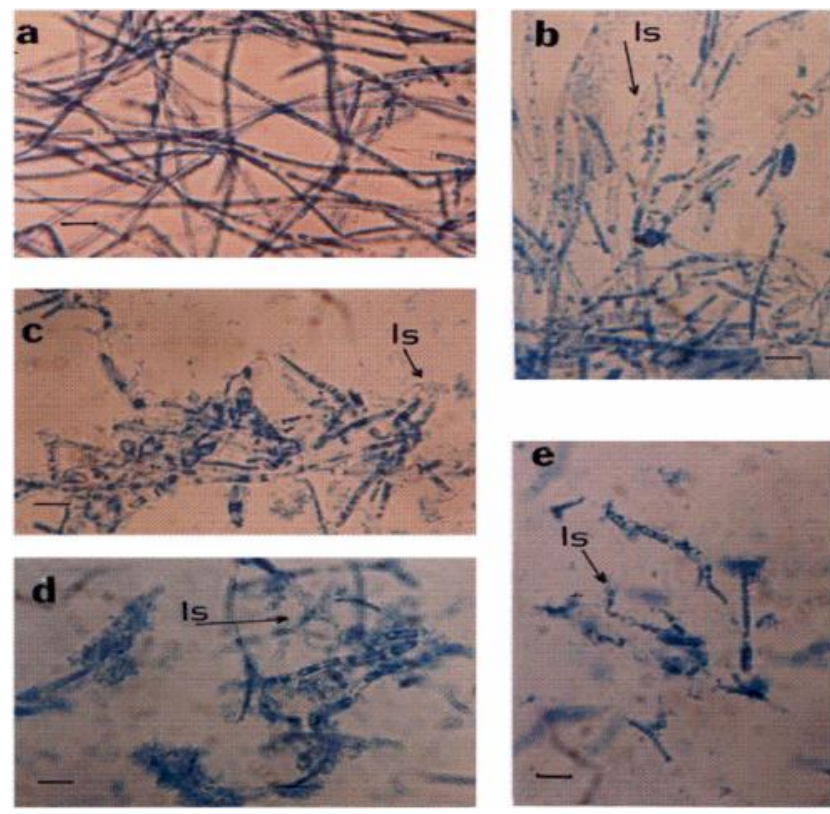

Gambar 3 Perubahan miselium jamur $F$. oxysporum yang diperlakukan dengan kitinase. a) kontrol tanpa pemberian kitinase, b) perubahan miselium setelah waktu inkubasi $1 \mathrm{jam}$, c) 2 jam, d) 4 jam dan e) 6 jam. (Perbesaran 400 x. Bar $=20$ $\mu \mathrm{m}$. (1s) miselium yang lisis. Pewarnaan laktofenol blue

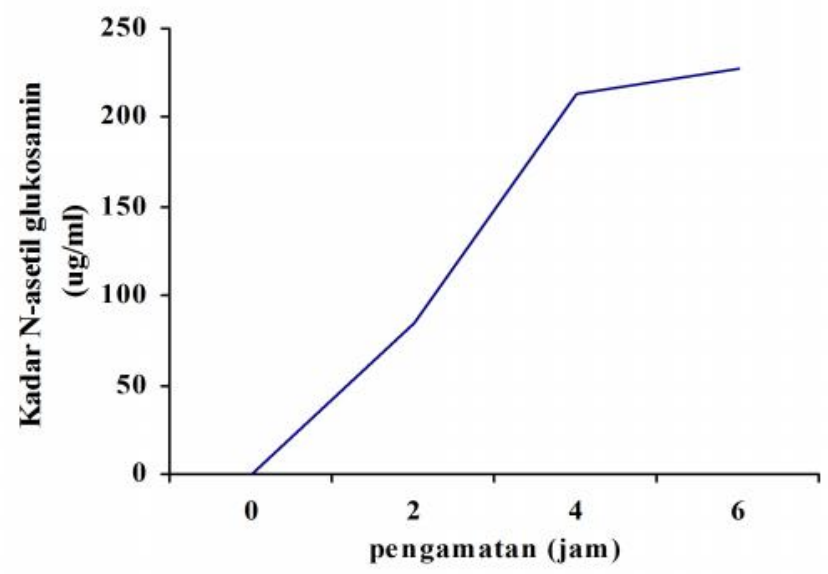

Gambar 4 Kadar NAG yang dibebaskan ke dalam medium selama terjadi lisis dinding sel jamur $F$. oxysporum oleh kitinase 
yang mengandung kitin. Dinding-sel yang melisis dan ditemukannya NAG pada medium membuktikan dugaan ini. Hal yang sama dibuktikan oleh Singh et al. (1999), dengan menambahkan enzim kitinase dari Streptomyces sp. 385 pada miselium jamur F. oxysporum $\mathrm{f}$. sp cucumerinum dan ke dalam medium juga ditemukan adanya NAG yang dibebaskan selama proses berlangsung.

\section{SIMPULAN}

Kitinase Streptomyces RKt 5 bersifat antijamur dan mampu melisiskan dinding sel dari potongan miselium jamur Fusarium oxysporum. Kemampuan antijamur dari kitinase Streptomyces RKt5 akan efektif jika mikrobia kitinolitik langsung berinteraksi dengan jamur patogen pada keadaan terinduksi kitin.

\section{UCAPANTERIMAKASIH}

Ucapan terima kasih ditujukan kepada Program BPPS Dikti Departemen Pendidikan Nasional atas bantuan dana yang diberikan selama melaksanakan penelitian ini.

\section{DAFTAR PUSTAKA}

Bormann, C., Baier, D., Ho, I., Raps, C., Berger, J., Jung, G. \& Schwarz, H. 1999. Characterization of a novel, antifungal, chitin-binding protein from streptomyces tendae $\mathrm{Tu}$ “901 that interferes with growth polarity. J. Bacteriol 181(24): 74217429.

Chernin, L., Ismailov, Z., Haran, S. \& Chet, I. 1995 Chitinolytic enterobacter agglomerans antagonistic to Fungal Plant Pathogens. Appl. Environ. Microbiol 61(5): 1720-1726.

Gohel, V., Singh, A., Vimal, M., Ashwini, P. \& Chhatpar, H.S. 2006. Review. Bioprospecting and antifungal potential Chitinolytic microorganisms. African J. of Biotechnology 5(2): 54-72.

Harighi, M.J., Zamani, M.R. \& Motallebi, M. 2007. Evaluation of antifungal activity of purified chitinase 42 from trichoderma atroviride PTCC5220. Biotechnology 6(1): 28-33.

Harjono \& Widyastuti, S.M. 2001. Antifungal activity of purified endochitinase produces by biocontrol agent trichoderma reesei against ganoderma philippii. Pakistan Journal of Biological Sciences 4(10): 1232-1234.

Hsu, S.C. \& Lockwood, J.L. 1975. Powdered chitin agar as a selective medium for enumeration of actinomycetes in water and Soil. Appl. Microbiol 29: 422-426.

Huan, C-J, Wang, T-K., Chung, S-C. \& Chen, C-Y. 2005. Identification of an antifungal chitinase from a potential biocontrol agent, Bacillus cereus 28-9. Journal of Biochemistry and Molecular Biology 38(1): 82-88.

Kamel, Z., Heikel, N. \& Fahmy, F. 1993. Extracellular chitinase from streptomyces species and its antifungal activity. Acta Pharmaceutica Turcica 35: 135-143.
Kamil, Z., Rizk, M., Saleh, M. \& Moustafa, S. 2007. Isolation and identification of rhizosphere soil chitinolytic bacteria and their potential in antifungal biocontrol. Global Journal of Molecular Sciences 2(2): 57-66.

Knezevic-Jugovic, Z., Petronijevic, Z. \& Smelcerovic, A. 2011. Chitin and Chitosan from Microorganisms. In; Kim $S-K(E d)$ Chitin, Chitosan, Oligosaccharides and Their Derivatives: Biological Activities and Applications. New York: CRC Press Taylor and Francis Group.

Labeda, D.P. \& Shearer, M.C. 1990. Isolation of Actinomycetes for Biotechnological Applications. In: D.P. Labeda (Ed.) Isolation of Biotecnological Organisms from Nature: McGrawHill Publishing Campany.

Matsumoto, K.S. 2006. Fungal Chitinases, In : Guevara-Gonzales R.G and Torres-Pacheco I (Eds). Advances in Agricultural and Food Biotechnology. Reseach Signpost, India. 289-304.

Muzarelli, R.A.A. \& Peter (Eds), M.G. 1997.Chitin Handbook. European Chitin Society.

Nwe, N, Furuike, T., \& Tamu H. 2011. Chitin and Chitosan from Terrestrial Organisms. In; Kim S-K (Ed) Chitin, chitosan, oligosaccharides and their derivatives : biological activities and applications. New York: CRC Press Taylor \& Francis Group.

Patil, R.S., Ghormade, V. \& Despande, M.V. 2000. Chitinolytic enzymes: an exploration. Enzyme and Microbial Technology 26: $473-483$.

Plummer, D.T. 1978. An Introduction to Practical Biochemistry. $2^{\text {nd }}$ Ed. Tata Mc Graw-Hill Publishing Company Ltd., New Dehli.

Prapagdee. B., Kuekulvong, C. \& Mongkolsuk, S. 2008. Antifungal potential of extraceilular metabolites produced by Streptomyces hygroscopicus against phytopathogenic fungi. Int. J. Biol. Sci 4(5): 330-337.

Sadeghi, A,A.R., Hessan, H., Askari, S., Aghighi \& Bonjar, G.H.S. 2006 Biological control potential of two streptomyces isolates on rhizoctonia solani, the causal agent of damping-off of sugar Beet. Pakistan Journal of Biological Sciences 9(5): 904-910.

Sahai, A.S. \& Manocha, M.S. 1993. Chitinases of fungi and plants: their involvement in morphogenesis and host-parasite interaction. FEMS Microbiol. Rev 11: 317-338.

Schoffelmeer, E.A.M., Klis, F.M., Sietsma, J.H. \& Cornelissen, B.J.C. 1999. The cell wall of fusarium oxysporum. Fungal Genet Biol 27: 275-282.

Shaikh, S.A. \& Deshpande, M.V. 1993. Review. Chitinolytic enzymes : Their contribution to basic and applied research. world J. Microbiol. Biotech 9: 468-475.

Singh, P.P., Shin, Y.C., Park, C.S. \& Chung, Y.R. 1999. Biological control of fusarium wilt of cucumber by chitinolytic bacteria. Phytopathology 89: 92-99.

Sivan, A. \& Chet, I. 1989. Degradation of fungal cell walls by lytic enzymes of Trichoderma harzianum. J. Gen. Microbiol 135: 675-682.

Yurnaliza, Margino, S. \& Sembiring, L. 2003. Isolasi aktinomisetes kitinolitik dari rhizosfer dan kompos. Komunikasi Penelitian 15(2): 27-35.

Yurnaliza, Margino, S. \& Sembiring, L. 2008. Kondisi optimum untuk produksi kitinase dari streptomyces Rkt5 dan karakterisasi pH dan suhu enzim. Biota, 13(3): 169-174.

Watanabe, T., Kanai, R., Kawase, T., Tanabe, T., Mitsutomi, M., Sakuda, M. \& Miyashita, K. 1999. Family 19 chitinases pof streptomyces species : characterization and distribution. Microbiol 145: 3353-3363. 